\title{
MULTI AXES GRINDING OF SCULPTURED SURFACES
}

\author{
Karel Jandečka \\ Department of Machining, West Bohemia University in Pilsen \\ jandecka@kto.zcu.cz
}

This paper presents the use of the CAD/CAM system Cimatron for free programming of NC grinding machines. NC technology use, first of all in milling, turning and drilling operations, is widely dispersed at present. Development of these technologies depends to some extent on the cutting tools which are to be produced and sharpened to a high quality. Usable properties of the cutting tools, e.g. the shape accuracy, the quality of function surfaces, etc., are inspired by the production technology used. This technology plays a main role in production and sharpening of powerful and complex shaped cutting tools.

Key words: Kinematics of grinding, sculptured surfaces, CAD/CAM system Cimatron, NC module, NC program

\section{References}

[1] Přikryl, Z., (1975) 'Teorie obrábění', SNTL/ALFA Praha.

[2] Švec, S., (1968) 'Řezné nástroje'.SNTL Praha.

[3] Jaromír, J., Mazanec, H., (1993) 'Diamantové a CBN nástroje pro průmyslové použiti', Plzeň, LAIWA PRESS.

[4] König, W., Klocke, F., (1996) 'Fertigungsverfahren', Band 2, Düsseldorf, VDI Verlag.

[5] Vasilko, K., Michel, D., Hrubec, J., (1984) 'Brusenie a ostrenie rezných nástrojov ', Bratislava, ALFA.

[6] Reklamní materiály firmy WALTER AG (2007).

[7] Reklamní materiály firmy SAACKE (2007).

[8] Reklamní materiály firmy SCHUNK (2007).

[9] Reklamní materiály firmy firmy RÖHM (2007).

[10] Kožmín, P., (2001) 'Broušení monolitních řezných nástrojů na NC bruskách', ICPM 2001, Ústí nad Labem, ÚTŘJ, ISBN 80-7044-358-8.

[11] Schimonyi, J., (1991) 'NC Programmierung für das Werkzeugschleifen', Berlin, Springer Verlag.

[12] Jandečka, K., (1996) 'Využití moderních CAD/CAM systémů prìi programování NC strojư', ZČU Plzeň.

[13] Manuál CAD/CAM systému CIMATRON ${ }^{\top \top}$ (2007)

[14] Reklamní materiály firmy URDIAMANT (2007)

[15] Manuál (2007) CAD/CAM systému CATIA V5R17

[16] Holešovský, F., Hrala M., (2002) 'Grinding of ceramic materials by diamond grinding wheel', Sborník 4.Medzinárodná vedecká konferencia RTO 2002 v Košicích, 22.-23.5.2002, str.5-8, ISBN 80-7099-796-6

[17] Holešovský, F., Hrala, M., (2001) 'Grinding Process and its Influence to Surface Integrity', Proceedings International Conference AMPT'01, Madrid 2001, Spain, pp.587-596, ISBN 84-95821-05-2

[18] Jersák, J., (2001) 'Matematický model broušení', In: II. Mezinárodní nástrojářská konference. Nástroje Tools 2001, Zlín. Univerzita Tomáše Bati ve Zlíně, Fakulta technologická, s. 141-147.

[19] Lukovitcs, I., Sýkorová, L., (1999) 'Stanovení řezivosti brousících kotoučů pro vysokovýkonné broušeni', In: Nástroje 99, Zlín, p. 96-102, ISBN 80-214-1426-X

[20] Jandečka, K., Česánek, J, Kapinus, V., Dvořák, P., Sova, F., (2005) 'Přehled současného Broušení tvarově složitějších nástrojư' Výzkumná zpráva KTO -1/05, ZČU v Plzni, Plzeň, 48 stran.

[21] Vrabec, M., Mádl, J., (2004) 'C programování v obráběni', Praha: Vydavatelství ČVUT, 92 s. ISBN 80-0103045-8.

[22] Beyer, H.-G. and Schwefel, H.-P. (2002)Evolution strategies. A comprehensive introduction. Natural Computing, 3-52, Kluwer, Academic Publishers. Netherlands,

[23] Castelino, K., D'Souza, R., and Wright, P. K. (2004) Tool-path Optimization for Minimizing Airtime during Machining.Journal of Computing and Information Science in Engineering, Volume 4, Issue 3, pp. 235-241, 
[24] Du, S. Simulation and Tool Path Optimization for the Hexapod Milling Machine. (2004) PhD, University of Dortmund. Vulkan Verlag, Essen,

[25] Foley, J.D., Van Damm, A., Feiner, S. K., and Hughes, J. F. (1995), Computer graphics, Principles and Practice. Addision-Weseley Professional,

[26] Gonzalez, R. C. and Woods, R. E. (2002) Digital Image Processing 2.edition. Prentice-Hall, New Jersey,

[27] Hudson, T. C., Lin, M. C., Cohen, J., Gottschalk, S., and Manocha, D. (1997) V-COLLIDE: Accelerated Collision Detection for VRML. Second Symposium on the Virtual Reality Modeling Language, New York City, NY, February 1997, 119-125,

[28] Huhse, J. and Zell, A. (2001) Evolution Strategy with Neighborhood Attraction - A Robust Evolution Strategy. Proceedings of the Genetic and Evolutionary Computation Conference, Edited by Spector, L. Goodmann, E. et al.

[29] Lin, M. C. and Gottschalk, S. (1998) Collision detection between geometric models: a survey. IMA Conference on Mathematics of Surfaces, Winchester, UK, 33-52,

[30] Mortenson, M. E. (1985) Geometric modelling. John Wiley \& Sons, Inc., My, C. A., Bohez, E. L .J., Makhanov, S. S., Munlin, M.,

[31] Phien, H. N., and Tabucanon, M. T. (2005) On 5-Axis Freeform Surface Machining Optimization: Vector Field Clustering Approach. International Journal of CAD/ CAM, Vol. 5, No.1, pp. 1598-1800,

[32] Niemöller, A. (1999) The wavelet transform as a tool in chemometrics: applications in NIR-spectrometry. PhD, University of Duisburg. Department of Chemistry, 1999

[33] Nievergelt, Y.(1999) Wavelets Made Easy. Birkhauser Verlag AG,Juni 1999

[34] Schwefel, H.-P. (1995) Evolution and Optimum Seeking. Sixth-Generation Computer Technology, John Wiley and Sons, New York,

[35] Stautner, M. and Zabel, A. (2005) Optimizing the Multi-Axis Milling Process via Evolutionary Algorithms. Proceedings of the 8th CIRP International Workshop on Modeling of Machining Operations, Chemnitz, Deutschland,

[36] Surmann, T., Kalveram, M., and Weinert, K. (2005) Simulation of Cutting Tool Vibrations for the Milling of Free Formed Surfaces. Proceedings of the 8th CIRP International Workshop on Modeling of Machining Operations, Chemnitz, Deutschland,

[37] Weinert, K., Mehnen, J., and Stautner, M. (2004) The Application of Multiobjective Evolutionary Algorithms to the Generation of Optimized Tool Paths for Multi-Axis Die and Mould MakingIn: Intelligent Computation in Manufacturing Engineering, 4th CIRP International Seminar on Intelligent Computation in Manufacturing Engineering, CIRP ICME '04, Sorrento, Naples, pp. 406-412,

[38] Weinert, K. and Stautner, M. (2002) An Efficient Discrete Simulation for Five-Axis Milling of Sculptured Surfaces. Production Engineering - Research and Development, Annals of the German Academic Society for Production Engineering, IX 1, pp. 47-51,

[39] Weinert, K. and Stautner, M. (2004) Generating Multiaxis Tool Paths for Die and Mold Making with Evolutionary Algorithms. In: Conference Proceedings Pt. II; Genetic and Evolutionary Computation GECCO 2004, Seattle, WA, USA, pp. 1287-1298,

[40] Weinert, K and Surmann, T. (2003) Geometric Simulation of the Milling Process for Free Formed Surfaces. In: Simulation Aided Offline Process Design and Optimization in Manufacturing Sculptured Surfaces, Witten Bommerholz, pp. 21-30,

[41] Weinert, K. and Zabel, A. (2001) Modelling, Simulation and Visualization of Simultaneous Five-Axis Milling with a Hexapod Machine Tool. In: Simulation in Industry, 13th European Simulation Symposium, ESS01 Conference Proceedings, 18.-20. October 2001, Marseille, France, pp. 344-348. [SCS] Publication, Erlangen

[42] Vidkovic, B. and Mueller, P. (1991) Wavelets for kids - A Tutoriál Introduction. Tutorial, Duke University,

[43] Yoon, J.-H. (2003) Tool tip gouging avoidance and optimal tool positioning for 5-axis sculptured surface machining. International Journal of Production Research, 41(10):2125-2142,

[44] Youn, U.W., Jun, Y., and Park, S. (2003) Interference-free tool path generation in five-axis machining of a marine propeller. The International Journal of Production Research, 41(18):4383-4402,

[45] Mourek, D., 'Problematika stanovení rozvalu šroubovitých drážek monolitních řezných nástrojů' Práce $k$ SDZ, ZČU v Plzni, Plzeň 2009. 